\title{
Phytochemical Screening of the Leaves Calpurnia Aurea (Ait.) Benth Extract
}

\author{
Hadera Brhane Gebreslassie $^{1 *}$, Alemseged Eyasu ${ }^{1}$ \\ ${ }^{I}$ Department of Chemistry, abbiy addi College of teacher education \& Educational leadership, Abbiy Addi, \\ Tigray Region, Ethiopia.
}

*Corresponding Author: Hadera Brhane Gebreslassie, Department of Chemistry, abbiy addi College of teacher education \& Educational leadership, Abbiy Addi, Tigray Region, Ethiopia.

\begin{abstract}
Background: Calpurnia aurea is a genus of Flowering Plants within the family of fabaceae. Calpurnia aurea from Ethiopia is known locally as "digitta" (Amharic), "市90-b-Hitsawits" (Tigrigna). In native countries like Ethiopia, traditionally, the leave of Calpurnia aurea is used for the treatment of syphilis, malaria, rabies, diabetes, lung TB, hypertension, diarrhoea, stomach-ache, bowel, bladder disorders, to induce uterine contractions, tapeworm, trachoma, ringworm, as well as vomiting, Dandruff, headache, eye diseases, to destroy maggots, to destroy bedbugs, to relieve itches, used as a fish-poison or as a cure for dysentery, cough and snake bite.
\end{abstract}

Objective: The main purpose of this study was interested to investigate the phytochemical analysis of the leaves extracts Calpurnia aurea.

Methods: Calpurnia aurea leaves were collected from around debrekerbe kebele, medebay zana wereda and north western Zone of Tigray Region, Northern Ethiopia. The collected plant material was dried and powdered using mortar and pestle and then extracted using serial exhaustive solvent extraction methods within four organic solvents: petroleum ether, chloroform, ethyl acetate and ethanol according to their increasing polarity index for 72 hours with mechanical shaking within 4 hours interval in average and it was filtered through Whatman No.1 filter paper and the filtrate was dried using Rotary evaporator.

Results: Calpurnia aurea leaves extract contains cardiac glycosides, carbohydrates, phenolic compounds and tannins, flavonoids, fixed oil \& fats, proteins, terpenoids, saponins, steroids and alkaloids, however there was difference observed based on extracting solvents used and strength of quality results in which, phenolic compounds and tannins, fixed oil and fats, steroids and cardiac glycosides were present in both petroleum ether and chloroform solvents; alkaloids, flavonoids, phenolic compounds and tannins, fixed oil and fats, amino acids and proteins, terpenoids, saponins and steroids were present in ethyl acetate solvent; carbohydrates, phenolic compounds \& tannins, flavonoids, amino acids \& proteins ,terpenoids, saponins, steroids and alkaloids present in ethanol solvent.

Conclusion: Therefore, it is obvious from this study that this medicinal plant has possessed different vital phytochemicals that helps in the medicinal properties of the studied plant commonly used in Medebayzana woreda around Debrekerbe kebele.

Keywords: Calpurnia aurea; phytochemicals; Phytochemical Analysis; Qualitative Analysis, standard method

\section{INTRODUCTION}

Medicinal plants have been a major source of treatment for human diseases since time immemorial. One fourth of the world population i.e. 1.42 billion people are dependent on traditional medicines, particularly plant drug for curing ailments ${ }^{[1]}$. They are safe, less toxic, economical and a reliable key natural resource of drugs all over the world. Medicinal herbs have been use in one form or another under indigenous systems of medicine ${ }^{[2]}$. Phytochemicals are bioactive chemicals of plant origin. They are regarded as secondary metabolites because the plants that manufacture them may have little need for them. They are naturally synthesized in all parts of the plant body; bark, leaves, stem, root, flower, fruits, seeds, etc. i.e. any part of the plant body may contain active components ${ }^{[3]}$. 
Phytochemicals are primary and secondary compounds. Chlorophyll, proteins and common sugars are included in primary constituents and secondary compounds have terpenoid, alkaloids and phenolic compounds ${ }^{[4]}$. The complete phytochemical screenings of medicinal plants should be carried out, because these secondary metabolites are responsible for medicinal activity of the plant. Numbers of plants were screened for secondary metabolites for their medicinal values ${ }^{[5]}$.

In order to promote herbal drugs, there is an urgent need to evaluate the therapeutic potentials of the drugs as per WHO guidelines and mentioned that $30 \%$ of the worldwide sales of drugs is based on natural products. Traditional indigenous medicine is limited to small tribal and geographical areas called "Little Traditions" are an excellent repository of knowledge about medicinal properties of botanical sources ${ }^{[6]}$.

The bioactive extract should be standardized on the basis of phytochemical compounds. Phytochemical screening of medicinal plants is very important in identifying new sources of therapeutically and industrially important compounds. It is imperative to initiate an urgent step for screening of plants for secondary metabolites. The present communication attempts to assess the status of phytochemical properties of medicinal plants to improve the health status of people and also to use in pharmaceutical products of commercial importance in the world ${ }^{[5]}$.

Calpurnia aurea is a genus of Flowering Plants within the family of fabaceae. The genus comprises shrubs or small trees in or along the margin of forests in many parts of Ethiopia and widely distributed in Africa from Cape Province to Eritrea and which also occurs in Southern India ${ }^{[7]}$. Literature survey brings to light that, all parts of the plant species has been used for different human and animal disease ${ }^{[8]}$. Calpurnia aurea from Ethiopia is known locally as "digitta" (Amharic),"Hitsawits" (Tigrigna) see Figure 1. The plant is used in traditional medicine of Ethiopia to treat diverse medical conditions. In native countries like Ethiopia, traditionally, the leave and powdered roots of Calpurnia aurea is used for the treatment of syphilis, malaria, rabies, diabetes, lung $\mathrm{TB}$, hypertension, diarrhoea, leishmaniasis, elephantiasis, fungal diseases, different swellings, stomach-ache, abscesses, bowel, bladder disorders, to induce uterine contractions ${ }^{[21]}$, used as an insecticide to kill lice ${ }^{[20]}$, and tapeworm, trachoma, ringworm, as well as vomiting, headache and eye diseases ${ }^{[22-25]}$, to destroy maggots, to destroy bedbugs, to relieve itches, used as a fish-poison or as a cure for dysentery, exhibit activity against amoebiasis and giardiasis, cough and snake bite ${ }^{[8,9]}$.

Table1. Scientific classification of the plant

\begin{tabular}{|c|c|c|}
\hline \multicolumn{2}{|c|}{ Scientific classification } & \\
\hline Kingdom: & Plantae & \\
\hline phylum & Angiosperms & 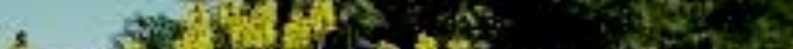 \\
\hline class & Eudicots & $\mathrm{eg}$ \\
\hline division & Rosids & 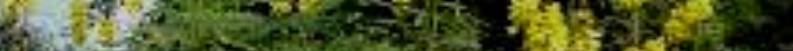 \\
\hline Order: & Fabales & \\
\hline Family: & Fabaceae & 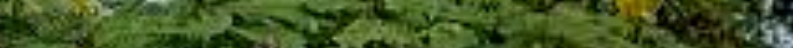 \\
\hline Genus: & Calpurnia & 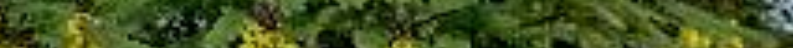 \\
\hline Species: & Aurea & 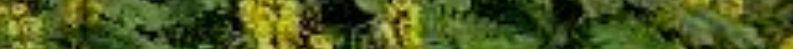 \\
\hline \multicolumn{2}{|c|}{$\begin{array}{l}\text { Binomial name: Calpurnia aurea } \\
\text { (Ait.) Benth. }\end{array}$} & Fig1a. leaves of Calpurnia aurea (By Hadera Brhane) \\
\hline \multicolumn{2}{|c|}{$\begin{array}{l}\text { Table-1. Scientific classification of } \\
\text { the plant }\end{array}$} & \\
\hline
\end{tabular}


Plant products have been part of phytomedicines since time immemorial. These can be derived from any part of the plant like stem bark, leaves, flowers, seeds and root i.e., any part of the plant may contain active components. Knowledge of the chemical constituents of plants is desirable because such information will be of value for the synthesis of complex chemical substances. Such phytochemical screening of various plants is reported by many research workers [4].

Thus, here in this present study, qualitative phytochemical analysis of the leaves extracts of Calpurnia aurea were screened by using standard methods. I hope that the findings from this work may add to the overall value of the medicinal potential of the plant species.

\section{MATERIALS AND METHODS}

\subsection{Plant Material Collection and Preparation}

The leaves of Calpurnia aurea were collected from around debrekerbe kebele, medebay zana wereda and north western Zone of Tigray Region, Ethiopia in February 2019. The selected medicinal plant has been candidate for research because of their superficial medicinal properties, and its traditional use for medicine. The plant material was identified its scientific name by Leul Kidane W/michael $(\mathrm{PhD})$ Assistant Professor in Plant Ecology \& Biodiversity Conservation Department of Biology, Mekelle University, Ethiopia. The leaves were washed with tap water to remove dirt's and impurities, dried at $25^{\circ} \mathrm{C}$ for 10 days in the absence of sunlight and powdered well using mortar and pestle and stored in an air tight container for further use.

\subsection{Preparations of the Extracts}

The powdered medicinal plant material was taken and subject to serial exhaustive solvent extraction, during this solvents of increasing polarity from a low polar (Petroleum ether) to a high polar solvent (ethanol) to ensure that wide polarity range of compounds could be extract, during extraction solvents were diffuse in to the plant material and solubilize the phytocompounds with similar polarity. For qualitative determination, the extracts were place in pre-weighed flasks before drying. The remaining plant parts residues were extracted with other solvents sequentially [26].

\subsection{Qualitative Phytochemical Analysis}

The qualitative analysis of secondary metabolites was carry out by the following standard methods of $[27,28]$.

\subsubsection{Test for Alkaloids}

Dragenderoff's Test: $2 \mathrm{ml}$ aliquot of the extract was treated with the Dragenderoff's reagent. An orange red precipitate was produce immediately and it was indicate the presence of alkaloids.

Mayer's test: $1 \mathrm{ml}$ aliquot of the extract was treated with few drops of Mayer's reagent. Formation of white precipitate or turbidity was produce and this shows the presence of alkaloids.

\subsubsection{Test for Flavonoids}

Shinoda's Test: $1 \mathrm{ml}$ of the extract was treating with magnesium turnings and 1-2 drops of concentrated $\mathrm{HCl}$. Formation of pink or red colour was show the presence of flavonoids.

Alkaline reagent Test: $1 \mathrm{ml}$ of the extract was treat with $5 \mathrm{ml}$ of sodium hydroxide. The formation of intense yellow colour was confirming the presence of flavonoids.

\subsubsection{Test for Tannins and Phenolic Compounds}

Ferric chloride test: $1 \mathrm{ml}$ of the extract was treated with few $\mathrm{ml}$ of $5 \%$ neutral ferric chloride. A dark blue or bluish black colour product was show the presence of tannins.

Gelatin test: $1 \mathrm{ml}$ of the extract was treated with few $\mathrm{ml}$ of gelatine solution; a white precipitate was form revealing the presence of tannins and phenolic compounds.

Lead acetate Test: $1 \mathrm{ml}$ of the extract was treated with few $\mathrm{ml}$ of Lead acetate solution. A white precipitate production was show the presence of tannins \& phenolic compounds.

\subsubsection{Test for Proteins}

Xanthoproteic Test: $1 \mathrm{ml}$ of extract was treated with 2 drop of concentrated HNO3. Development of yellow colour was indicating the presence of proteins. 
Biuret test: $1 \mathrm{ml}$ of extract was treated with $1 \mathrm{ml}$ of $40 \%$ sodium hydroxide solution and 2 drops of $1 \%$ copper sulphate reagent. Appearance of violet colour was indicating the presence of proteins.

\subsubsection{Test for Reducing Sugars}

Benedict's test: To $1 \mathrm{ml}$ of the extract, was added to $5 \mathrm{ml}$ of Benedict's solution and keep in boiling water bath for $5 \mathrm{~min}$. Red, yellow or green precipitate was indicate the presence of reducing sugars.

\subsubsection{Test for Cardio Glycosides}

Keller-Killani Test: To the solution of the extract in glacial acetic acid, few drops of ferric chloride and concentrated sulphuric acid was add, and observe for a reddish brown coloration at the junction of two layers and the bluish green colour in the upper layer was indicates the presence of glycosides.

\subsubsection{Test for Saponins}

Frothing Test: About $1 \mathrm{ml}$ of the extract was dilute separately with $20 \mathrm{ml}$ of distilled water and was shake in a graduated cylinder for 15 minutes. A $1 \mathrm{~cm}$ layer of foam was indicates the presence of saponins.

\subsubsection{Test for Fixed Oils and Fats}

Spot test: A small quantity of the extract was press between what man No 2-filter papers. Oil stains on the filter paper was indicate the presence of fixed oil.

\subsubsection{Test for Terpenoids}

Liebermann test: To $1 \mathrm{ml}$ of extract $3 \mathrm{ml}$ of acetic acid and few drops of concentrated sulphuric acid were added. The colour change from red to blue was indicating the presence of terpenoids.

\subsubsection{Test for Steroids}

Libermann-Burchards test: To $1.0 \mathrm{ml}$ plant extract, $1.0 \mathrm{ml}$ of concentrated sulphuric acid was added followed by the addition of $2.0 \mathrm{ml}$ of acetic anhydride solution. A greenish colour was developed and it turns blue to indicate the presence of steroids.

Salkowski's test: To $1 \mathrm{ml}$ of extract, $1 \mathrm{ml}$ of concentrated sulphuric acid was added carefully along the sides of the tube. The red colour was produced in the chloroform layers then it indicated the presence of steroids.

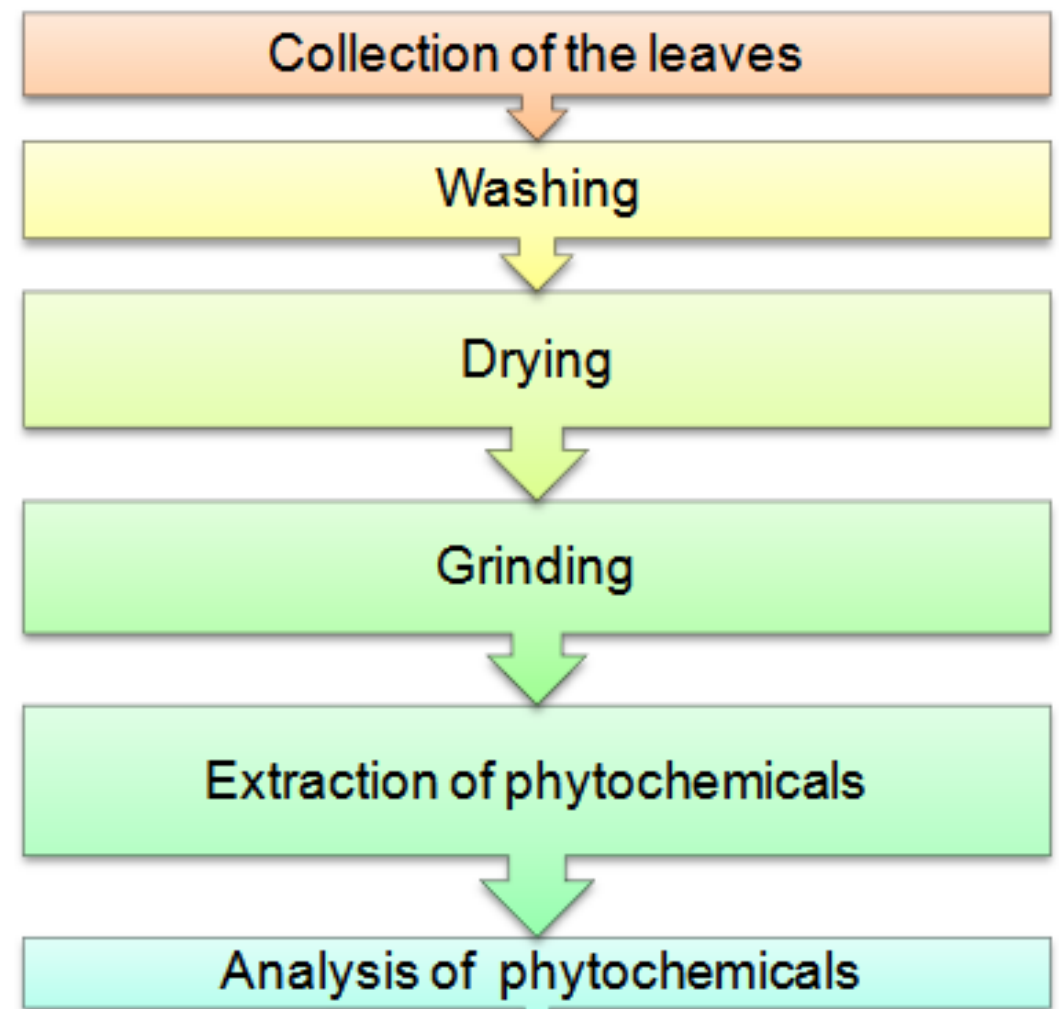

Fig1. Methodology summary 


\section{RESULTS AND DISCUSSION}

\subsection{Results}

Table1. Results of Preliminary Phytochemical Screening of the leaves of Calpurnia aurea plant species.

\begin{tabular}{|c|c|c|c|c|c|c|}
\hline \multirow[t]{2}{*}{$\mathrm{S} / \mathrm{N}$} & \multirow[t]{2}{*}{ Phytochemicals } & \multirow[t]{2}{*}{ Standard Tests } & \multicolumn{4}{|c|}{ Solvent Extract } \\
\hline & & & $\begin{array}{l}\text { Petroleum } \\
\text { ether }\end{array}$ & Chloroform & $\begin{array}{l}\text { Ethyl } \\
\text { acetate }\end{array}$ & Ethanol \\
\hline \multirow[t]{2}{*}{1} & \multirow[t]{2}{*}{ Alkaloids } & Dragendroff's Test & - & - & + & + \\
\hline & & Mayer's Test & - & - & - & - \\
\hline \multirow[t]{2}{*}{2} & \multirow[t]{2}{*}{ Flavonoids } & Alkaline Reagent Test & + & - & + & + \\
\hline & & Shinoda's Test & + & - & - & - \\
\hline 3 & Cardiac Glycosides & Keller-Killiani's Test & + & + & - & - \\
\hline 4 & Terpenoids & Liebermann Test & + & - & - & + \\
\hline \multirow[t]{3}{*}{5} & \multirow{3}{*}{$\begin{array}{c}\text { Phenolic } \\
\text { Compounds and } \\
\text { Tannins }\end{array}$} & Ferric chloride Test & - & + & + & + \\
\hline & & Lead acetate Test & - & - & - & + \\
\hline & & Gelatin Test & + & - & + & - \\
\hline 6 & Fixed oil and fats & Spot test & + & + & + & - \\
\hline 7 & Saponins & Frothing test & - & - & + & + \\
\hline \multirow[t]{2}{*}{8} & \multirow[t]{2}{*}{ Steroids } & $\begin{array}{c}\text { Liebermann- } \\
\text { Burckhardt's Test }\end{array}$ & + & + & + & + \\
\hline & & Salkowski's Test & - & - & - & + \\
\hline 9 & Reducing sugars & Benedict's test & + & - & - & + \\
\hline \multirow[t]{2}{*}{10} & \multirow[t]{2}{*}{ proteins } & Biuret test & - & - & + & - \\
\hline & & Xanthoproteic test & - & - & + & + \\
\hline
\end{tabular}

+ indicates $=$ present,$\quad-$ indicates $=$ absent

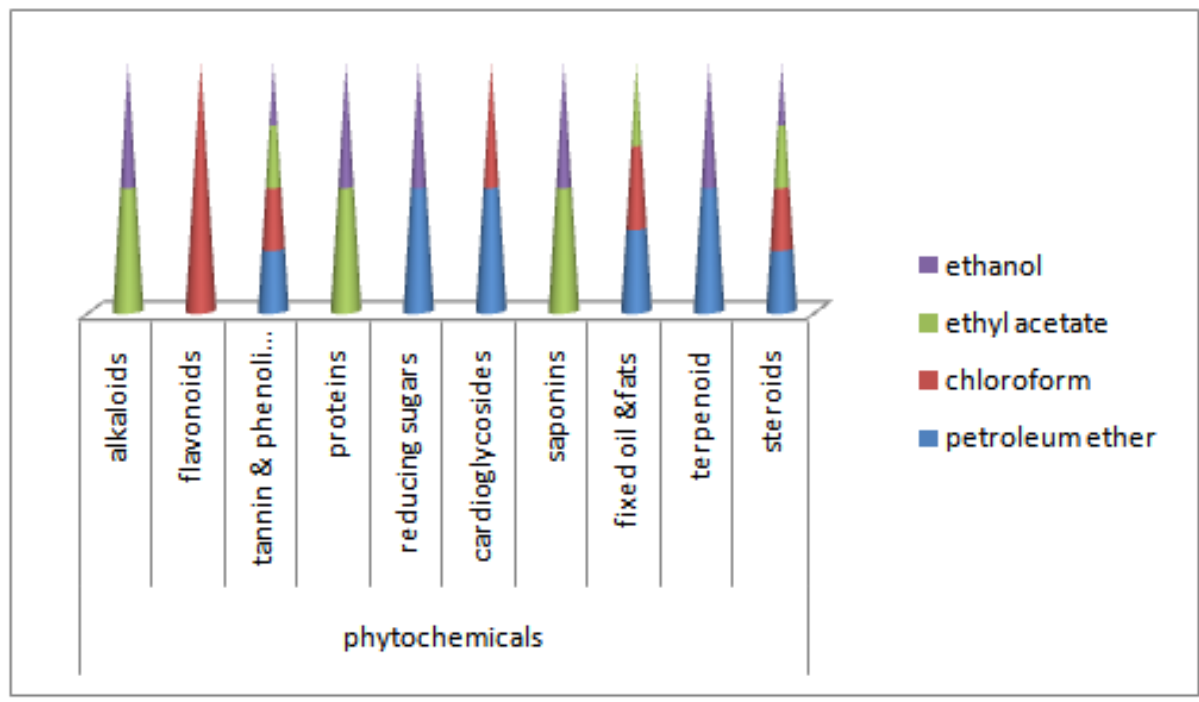

Fig2. Phytochemical constitutes $v_{s .}$ solvent using for Extraction

\subsection{Discussion}

According to different findings made, preliminary phytochemical analysis of the plant extracts indicated presence of different phytochemicals. The hydro alcoholic extract of leaves of Calpurnia aurea was screened for the presence of bioactive plant chemical constituents as alkaloids, terpenoids, flavonoids, steroids and phytosteroids, tannins, saponins, phenols and cardiac glycosides using standard qualitative phytochemical screening test procedures $[15,16,17,4,18]$. The preliminary phytochemical analysis of $70 \%$ ethanolic extracts from the C. aurea seeds showed the presence of tannins, flavonoids, terpenoids, saponins, steroids, glycosides, alkaloids compounds [19]. The stem and bark hexane extract of Calpurnia aurea yielded the widely studied isoflavonoids and alkaloid type phytochemicals [5]. The phytochemical screening and qualitative estimation of Calpurnia aurea seeds and leaves showed that the leaves were rich in flavones and polyphenols than the seeds, yet the seeds are rich in alkaloids and tannins than the leaves Calpurnia aurea [4]. 
Here in this present study, though the degree is different in similar manner,

As shown in the table -1- or figure-3 the preliminary phytochemical screening as certained the presence of bioactive secondary metabolites such as flavonoids, Cardio glycosides, steroids, tannins and saponin which confirmed that, presence pharmacologically active components, the polar compounds were detected in polar fractions and non-polar in non-polar solvents. Further it is clear from the data given in table -1- or figure-3 the number of phytochemical extracted from leaves of Calpurnia aurea as the polarity i.e. ethanol shown the presence of maximum numbers of phytochemical while the ethyl acetate and chloroform showed four classes of bioactive compounds, steroids, cardiac glycoside and terpenoids were found in all organic extracts, amusingly none of the extracts shown the presence of alkaloids.

\section{CONCLUSiON}

According to this study, the ethanol extract of Calpurnia aurea leaves gave the highest phytocompounds of extraction and followed by ethyl acetate in contrast to petroleum ether and chloroform extract indicating that the leaves extract contained more polar compounds than non-polar compounds.

The plant leaves parts of different four solvent extracts were found to possess cardiac glycosides, tannins, flavonoids, phenolic compounds, alkaloids, steroids and saponins. However, as result data analysis revealed, there is difference in degree of contents of these phytochemicals based on the solvents used for sample extraction. The phytochemical screening test results have revealed that phenolic compounds, tannins and steroids are the strongest detected components in the leaves part of the plant species next to which fixed oil and fats were the strongly detected phytochemicals.

Finally, the medicinal plant Calpurnia aurea leaves extract appears to be rich in secondary metabolites as the same to that suggested by different authors on other parts of the plant species such as seeds and roots widely used in traditional medicine to combat and cure various ailments, such as syphilis, malaria, rabies, diabetes, hypertension, diarrhoea, leishmaniasis, trachoma, elephantiasis, fungal diseases and different swellings. Exploitation of these pharmacological properties involves further screening of these active ingredients by implementation techniques of extraction, purification, separation, crystallization and identification. The study findings support the use of this one plants in the determinations of different functional groups in organic chemistry likes alkenes, alcohols, carboxylic acids etc. This plant can also be used to find out bioactive natural products that may hand out as leads for the enlargement of latest pharmaceuticals.

\section{ACKNOWLEDGEMENT}

The authors sincerely thank to Leul Kidane W/michael (PhD) Assistant Professor Department of Biology, Mekelle University, Mekelle, Ethiopia supporting on identifying the scientific name of the Medicinal plant; Department of Natural science, Abbiy Addi College of teacher education \& Educational leadership, Abbiy Addi, Tigray Region, Ethiopia and for Mr.Yberh Gidey \& Mr.Huluf Gebremicaal from chemistry laboratory for their kind assistance during laboratory works.

\section{REFERENCES}

[1] S. Kala, M. Johnson, N. Janakiraman, A. Anto Arockiaraj, S. Iyan Raj and Dorin Bosco, Pharmacognostic and phytochemical studies on some selected ethnomedicinal plants of Tamilnadu, South India, Int. J. Med. Arom. Plants, Vol. 1, No. 2, 2011, 89-94.

[2] N. K. Dubey (2004) “Global promotion of herbal medicine: India’s opportunity”. Curr Sci 86: 37-41.

[3] Tiwari, P., Kumar, B., Kaur, M., Kaur, G., and Kaur, H. 2011. Phytochemical screening and Extraction: A Review. Internationale Pharmaceutica Sciencia, 1(1):98-106.

[4] D. Krishnaiah, R. Sarbatly, A. Bono (2007) "Phytochemical antioxidants for health and medicine: A move towards nature". Biotechnol Mol Biol Rev 1: 97-104.

[5] G. Natesan, N. Haile, M. Umeta, D. Seifu (2015) "Phytochemical Screening and Assessment of In Vitro Antioxidant Activities of Calpurnia Aurea Seeds and Leaves". Ijppr.Huma 2:1-12.

[6] WHO Traditional Medicine Strategy (2002)World Health Organization, Geneva 2-5.

[7] E. Korir, J. K.Joyce, R. C. Neil, M. Nivan, A. K. Neil (2014) "Isoflavones from Calpurnia Aurea Subsp. Aurea and Their Anticancer Activity.” Afr J Tradit Complement Altern Med 11: 33-37.

[8] Gemechu, G. Mirutse, W. Adane, A. Gobena (2013). "In vitro Anti-mycobacterial activity of selected medicinal plants against Mycobacterium tuberculosis and Mycobacterium bovis Strains". BMC Complementary and Alternative Medicine 13: 291. 
[9] H. Tadeg (2004) "Phytopharmaceutical Studies of Some Selected Medicinal Plants Locally Used in the Treatment of Skin Disorders”. B. Pharm, Addis Abeba University, Ethiopia.

[10] H. Tadeg, E. Mohammed, K. Asres, T. Gebre-Mariam (2005) "Antimicrobial activities of some selected traditional Ethiopian medicinal plants used in the treatment of skin disorders". J. Ethnopharmacol 100: 168-175.

[11] H. G. Sunil, D. P. Shweta, S. U. Patil (2012) "Preliminary Phytochemicals Screening and TLC Analysis of Ficus racemosa Leaves". J. Chem. Pharm. Res 4:2380-2384.

[12] S. Khalil, A. A. Rahim, K. K. Taha, K. B. Abdallah (2013) "Characterization of Methanolic Extracts of Agarwood Leaves". Journal of Applied and Industrial Science 1: 78-88.

[13] G. A. Ayoola, H. A. Coker, S.A. Adesegun, A. A. Adepoju-Bello, K. Obaweya et al. (2008) "Phytochemical screening and antioxidant activities of some selected medicinal plants used for malaria therapy in South Western Nigeria". Trop J Pharm 7: 1019-1024.

[14] J. Parekh, S. Chanda (2007) "Screening of aqueous and alcoholic extracts of some Indian medicinal plants for antibacterial activity". Indian J. Pharm Sci 68: 835-838.

[15] S. Kumar, U.K. Sharma. A.K. Sharma, A.K. Pandey (2012) "Protective efficacy of Solanum xanthocarpum root extracts against free radical damage: phytochemical analysis and antioxidant effect". Cellular and Molecular Biology 58: 171-178.

[16] K. Tiwari (2001) "Imbalance in antioxidant defense and human diseases: Multiple approach of natural antioxidants therapy". Current science association 81: 1179-1187.

[17] Z. Birhanu, M. A. Wuhab, T. Abula (2015) “Antimalarial Activity of Calpurnia Aurea Hydro alcoholic Leaf Extract In Mice Infected With Plasmodium Berghei”. Archives 2: 73-79.

[18] E. Mebrahtu, S. Workineh, G. Mirutse (2013) "In vivo antimalarial activity of hydromethanolic leaf extract of Calpurnia aurea (Fabaceae) in Mice infected with chloroquine sensitive Plasmodium berghei". Int. J. Pharm.Pharmacol 2: 123-142.

[19] Umer, K. N. Tekewe (2013) "Antidiarrhoeal and antimicrobial activity of calpurnia aurea leaf extract". BMC complementary and alternative medicine 13: 21.

[20] N. Mulata, D. Seifu, M. Umeta, E.Wendwesson, G. Natesan (2015) "Protective Effects of Calpurnia aurea Seed Extract on HAART Hepatotoxicity". EJMP 9: 1-12.

[21] Waka M, Hopkins RJ, Curtis C. Ethnobotanical survey and testing of plants traditionally used against hematophagous insects in Eritrea. Journal of ethnopharmacology. 2004; 95(1):95-101.

[22] Desta B. Ethiopian traditional herbal drugs. Part III: Anti-fertility activity of 70 medicinal plants. Journal of Ethnopharmacology. 1994;44(3):199-209.

[23] Jansen PCM. Spices, condiments and medicinal plants in Ethiopia, their taxonomy and agricultural significance: Pudoc; 1981.

[24] Abebe W. A survey of prescriptions used in traditional medicine in Gondar region, northwestern Ethiopia: general pharmaceutical practice. Journal of ethnopharmacology. 1986;18(2):147-65.

[25] Asres K, Bucar F, Kartnig T, Witvrouw M, Pannecouque C, De Clercq E. Antiviral activity against human immunodeficiency virus type $1(\mathrm{HIV}-1)$ and type 2 (HIV-2) of ethnobotanically selected Ethiopian medicinal plants. Phytotherapy Research. 2001;15(1):62-9.

[26] Tadeg H, Mohammed E, Asres K, Gebre-Mariam T. Antimicrobial activities of some selected traditional Ethiopian medicinal plants used in the treatment of skin disorders. Journal of ethnopharmacology. 2005;100(1):168-75.

[27] Das K, Tiwari RK, Shrivastava DK. Techniques for evaluation of medicinal plant products as antimicrobial agent: Current methods and future trends. J Med Plants Res 2010;4:104-11.

[28] Harborne JB. In: Phytochemical Methods. 3rded. London: Chapman and Hall Ltd.; 1998. p. 15-8.

[29] Trease GE, Evans WC. Pharmacognosy. 12th ed. Philadelphia, PA: ELBS Publication Baillier Tindall, East Bournem; 1996. p. 344-539.

Citation: Hadera Brhane Gebreslassie, "Phytochemical Screening of the Leaves Calpurnia Aurea (Ait.) Benth Extract”. International Journal of Clinical Chemistry and Laboratory Medicine (IJCCLM), 5(4), pp.18-24, DOI: http://dx.doi.org/ 10.20431/2455-7153.0504004.

Copyright: (c) 2019 Authors. This is an open-access article distributed under the terms of the Creative Commons Attribution License, which permits unrestricted use, distribution, and reproduction in any medium, provided the original author and source are credited. 